\title{
The construction of the African being in South African history textbooks
}

\section{Marshall Maposa}

\begin{abstract}
This study is rooted in the move by the South African government at the turn of the $21 \mathrm{st}$ century to spearhead the conception of what then President Thabo Mbeki referred to as an African Renaissance. This move entailed cultivating an African consciousness; education being one of the key tools. With textbooks still playing a critical role in the education system, I analysed South African National Curriculum Statement-compliant history textbooks in order to understand the construction of the African being. I employed a critical discourse analysis methodology to analyse a sample of four contemporary South African history textbooks with a focus on the chapters that deal with post-colonial Africa. At a descriptive level of analysis, the textbooks construct the African being as five-dimensional: the spatial, the physical, the philosophical, the cultural and the experiential notions. The interpretation is that the African being is constructed as multidimensional. I use postcolonial theory to explain that while the macro-level of power produces the dominant discourses, the micro-level of the citizen also contributes to the discourses that permeate the history textbooks. Indeed, the production of textbooks is influenced by multifarious factors that when the discourses from the top and from below meet at the meso-level of textbook production, there is not just articulation but also resistance, thus producing heteroglossic representation of the African being.
\end{abstract}

\section{Background, contextualization and introduction}

By the turn of the 21 st century, the then South African President, Thabo Mbeki, had espoused the concept of an African Renaissance as one of the objectives of his country's domestic and foreign policy (Mbeki, 1999). Originally articulated by Cheik Anta Diop from the 1946 to 1960, the African renaissance, in its idealistic sense, envisaged a marked shift in the form of African consciousness on which African unity, renewal and development can be based (Diop, 2000). Although the appeal of the African Renaissance endeavour has diminished since the end of Mbeki's tenure in 2008, one of its significant impacts was the transmutation of the Organisation of African Unity (OAU) into the African Union (AU) in 2002. 
Mbeki's positioning of South Africa in the African Renaissance project is noteworthy if one considers South Africa's position on the African continent. South Africa boasts one of the continent's largest economies and its relative political stability has earned the country significant influence. Nonetheless, it should be remembered that Mbeki is quoted to have said on his return from exile: "It was very clear that something had happened in South African society, something that didn't happen in any other African society. The repeated observation is that 'These South Africans are not quite African, they're European"' (Adebajo, 2004, p.175). Therefore, Mbeki's (1996) I am an African speech of can be viewed as rebuttal of the notions of South African exceptionalism on the continent. It should be noted that the issue of the Africanness in South Africa is topical even in the present-day and more discussion of scholarly arguments on Africanness will be done in the literature review section of this article.

Discourses at the macro-level also echo the scholarly arguments. For example, President Zuma is quoted to have claimed: "Even if I live in the highest building, I am an African ... Because if you are not an African, you cannot be a white, then what are you" (City Press, 3/11/2012)? Yet, despite such an unequivocal pronouncement, the same man brewed a storm with this contentious statement on debate over e-tolls: "We [South Africans] can't think like Africans in Africa. It's not some national road in Malawi" (Mail \& Guardian, 22/10/ 2013).

The two speeches by Zuma quoted above show two things about discourses on Africanness at the macro-level. On one hand, they uphold the Africanness of South Africans, the connotation being that Black South Africans are African. This discourse is not just unofficial, seeing as official documents in South Africa mainly refer to Africanness with racial connotations. For example the census results by Statistics South Africa (2012) stated that the racial groups found in South Africa are Black African, Coloured, Indian/Asian, White and Other. These official categories support the use of the term African with reference to Black people. On the other hand, the second speech questions the Africanness of South Africans (including Blacks). This contradiction can then be taken to be reflecting the contending discourses on Africanness in South Africa. It should be noted though, that there also exists another contending discourse on how everyone who lives in South Africa is sometimes referred to as African. This is the case with Thabo Mbeki's I am an African speech and the case of the 2010 FIFA World Cup during which slogans such as 'We are all African' were promoted and all 
participants and visitors were told they were 'Welcome home' on the pretext that Africa is from where all humankind, in an evolutionary sense came. ${ }^{1}$

Discourses on Africanness are also evident at the micro-level. For example, one Khaya Dlanga wrote on news24.com (4 January, 2011) that "White people are African too!" This was in response to an article by Sentletse Diakanyo titled "We are not all Africans, black people are!" These social media engagements provide evidence of the debates on Africanness in the South African context. Evidently, there is no agreement on what constitutes an African being. While people do not necessarily always share the same point of view, there is need for a sustainable conception of Africanness considering South Africans have to interact with other Africans. The interaction between South Africans and people from other African countries has increased as a result of intensified immigration. According to Statistics South Africa (2013), 141550 temporary resident permits were granted by the Department of Home Affairs in 2012 alone, with the top two contributing countries being Zimbabwe and Nigeria. This excludes the large numbers of illegal immigrants that have found their way into South Africa as economic and political refugees. There has never been any official confirmation of the number of illegal immigrants, but the South African Police Service (2009) estimated the number to be as much as six million, the majority being Africans. Considering the schisms that result from immigration, conceptions of the African being are important. Harris (2002) assembled a collection of newspaper articles representing African foreigners as "a disease or a plague descending onto the country" (p.176). Not only do the media influence its audience; they also write to satisfy a market, meaning that these negative discourses might be acceptable in certain sections of the society. This has been manifested by spurts of xenophobic violence, the worst of which was in 2008 when approximately 62 people died (McKnight, 2008). It should be cautioned though that xenophobia is not an exclusively South African phenomenon as there are numerous other cases throughout the African continent and the world (Tadjo, 2008; Duponchel, 2013).

The issues raised above reflect some of the discourses on Africanness within the South African context at both the macro and micro levels. One of the ways through which the tensions evident in such discourses can be eased is through

An example is the Mogale City website which was headlined 'WELCOME HOME: Mogale City welcomes visitors, football fans and the 2010 FIFA World Cup teams to the city of human origin.' 
education, particularly school history. Even the then Department of Education (2000, p.6) conceded that while everyone possessed a form of consciousness, "the value of the formal study of history is that it aims to develop this latent consciousness into a conscious consciousness". This means that school history can also develop within learners an African consciousness. The officially sanctioned historical narratives can be found in textbooks. However, my literature search did not show any study that has been done on how history textbooks construct the African being. It is on the basis of such a background that I undertook this research with the following key question in mind: How is the African being constructed in contemporary South African History textbooks? The aim of the study was therefore to analyse the textbooks and understand the nature of the African being that is constructed therein.

\section{Literature review}

I consulted literature that deals with discourses on Africanness, which is, in other cases, referred to as Africanity (Dei, 1994; Mazrui, 2005) or African personhood (Fairfax, 2011). Literature shows that the African being is not a straightforward construct. Through history, the criteria that have been used to qualify one as an African ranged from geographical location, race, language, culture and attitude to experiences (Armah, 1999).

At a simple level, reference to geographical location or habitation is often used to determine who a person is. In this sense, for instance, an inhabitant of Africa is basically then regarded as an African. While this is an easy criterion for Africanness, it should be noted it has its complications. To confirm this, Van Dijk (2006, p.19) quotes South African writer, Zakes Mda to have asserted that, "until about 100 years ago the inhabitants of the continent did not generally refer to themselves as Africans ... They recognised and celebrated primarily various identities that were based on ethnicity, clan, family, gender and class." And with increased globalisation and migration, defining Africans by geographical location is now open to further criticism. In an effort to qualify Africanness, Mazrui (2005, p.70) maintains that all indigenous inhabitants of Africa can be classified as "Africans of the soil". In reference to the same classification, Dei (1994, p.3) labels himself "a continental African by birth." While such classifications are meant to reduce uncertainty, both of them unwittingly have a connotation that there are Africans of various kinds. 
A related understanding is that Africanness is determined by origin, implying that everyone who is of African heritage is an African. The problem with referring to origin from Africa is that "not only is Africa 'the cradle of humankind' but, from a genetic perspective, all people continue to be Africans - at least more than anything else" (Van Dijk, 2006, p.25). While this argument has had scientific support, it remains problematic because there are other aspects - such as race and culture - that continue to be used to differentiate people of the world.

Regarding race, Dei $(1994$, p.5) categorically states that "African is a race." This is in line with Pan-Africanism which also applies Africanness synonymously with Blackness (Mboukou, 1983). However, Blackness in itself is an ambiguous concept and it may mean different things in, say the USA and South Africa (Hollinger, 2005). These differences have meant that some people would then be viewed to be more African than others. An example of a kind of hierarchy developed to determine Africanness is illustrated by Mazrui's (2005) typology where native Africans referred to as Africans of the soil, while those in the Diaspora are "Africans of the blood" (p.70). The position of Arab Africans then becomes tricky considering that some race theories regard them to be of "Caucasoid stock" thus view them as European in origin (Fage and Tordoff, 2002, p.7).

Race issues also get entangled with other criteria such as language and culture. For instance the term Bantu, ${ }^{2}$ in varying contexts, has assumed both linguistic and racial designations (Fage and Tordoff, 2002). Therefore, the use of language proficiency as a determination of Africanness is evidently fraught with problems. According to Mazrui (2006, p.68) a family only becomes African American "when it loses its ancestral language". Using this logic a European who settles in Africa and adopts an African spoken language will have lost their Europeanness to become African and as long as they speak their home language they remain European.

Culture has also been considered as a criterion for Africanness. Mamdani (1999, p.129) contends that there is what can be called an African culture and the Creolised people in southern and east Africa are culturally "neither wholly African nor wholly non-African". The claim here is that, in the case of South Africa, people that are categorised as Coloured are not culturally African.

2 As noted earlier, Bantu literally refers to people, although some linguists have adopted it as a linguistic classification. Under Apartheid it was a collective noun for black people. 
This contention is not limited to mixed-race people only, with North Africans being viewed as culturally separate from Sub-Saharan Africans (Grinker and Steiner, 2005). Nevertheless, Dei (1994, p.4) claims that Africans "wherever they may be" have cultural similarities that can be identified in "social structure, music, burial customs, and folk beliefs". However, not all scholars agree. William (2003, p.243) warns that "talk of African identity in terms of culture is at best precarious". And Appiah $(1992$, p.26) further declares that:

\footnotetext{
Whatever Africans share, we do not have a common traditional culture, common languages, a common religious or conceptual vocabulary ... we do not even belong to a common race ... The central cultural fact of African life remains not the sameness of Africa's cultures, but their enormous diversity.
}

There is also a tendency to refer to experience as the missing African common denominator. The argument would be that Africans share a common history (usually in reference to Western colonisation) and that experience has shaped them to be who they are to the extent of determining an expected African behaviour. William (2003, p.244) claims that an African should have the memory "of a member of an exploited race". While it might be tempting to generalise the African experience of colonisation, it should be noted that the actual experiences were not the same and lasted for differing spells.

The loopholes identified by the arguments thus far show how scholars do not concur on what defines an African being. It also shows that not everything that is in Africa is always regarded as African. What is also evident is that views on the African being have been changing over time. Appiah (1992, p.73) quotes the novelist Chinua Achebe to have captured this dilemma, albeit with positivity: "There isn't a final identity that is African. But, at the same time, there is an identity coming into existence. And it has a certain context and meaning." This optimistic argument is in line with Ottaway's (1999) view that invented identities such as Africa and the African can actually become real. It is therefore important to research on how much Africanness is made real in history textbooks. as noted in the introduction, there is a gap in literature on the construction of the African being in history textbooks.

History textbooks have been a central part of the teaching and learning of the subject for over five hundred years in Western education (Apple and Christian-Smith, 1991; Sleeter and Grant, 1991; Mirkovic and Crawford, 2003; Crawford, 2000; Nicholls, 2006). The South African education system is still also heavily reliant on textbooks as was demonstrated by the Limpopo textbook saga whereby some schools in the province were bereft of textbooks 
leading to government investigation, not just in Limpopo, but in other provinces such as the Eastern Cape (Madonsela, 2013; Chisholm, 2013).

The language that is used in the history textbooks is crucial to the construction of what Naseem $(2008$, p.25) refers to as "educational discourse". The language being referred to includes the "use of metaphors, codes, previously accepted conceptions, connotations, and other semantic devices" (Frier, 1998, p.196). The words in the History textbooks are connected with various concepts, consciousness included, and through an analysis of the language in the textbook a researcher can discover how the concepts are constructed and the nature of the text book producer's thought processes (Donlan, 1980; Foster and Crawford, 2006). In order to understand the language, one should have an understanding of the meaning of text, be it verbal or visual LaSpina, 1998; Janks, 1997; Väisänen, 2008. Such scholarly views therefore guided me to analyse South African history textbooks in order to understand their construction of the African being.

\section{Theoretical framework}

In this study, 'post-colonial' refers to a temporal marker while 'postcolonial' refers to the theory (St-Pierre, 1997). The major contributors in the postcolonial theory include Fanon (1961), Said (1978), Spivak (1993) and Bhabha (1994). They challenge the dominant Western discourses that they claim to be the foundation of colonialism. Critics, however, warn that the effects of colonialism cannot be wiped out and "the return to one's 'native' land is a paradigmatic impossibility" (Baker Jr., Dovey, Jolly, and Deinert, 1995, p.1047). This therefore makes hybridity a characteristic of postcoloniality (the condition of being postcolonial). In Mbembe's view, (as cited in Hitchcock, 1997, p.236), this "chaotic plurality', one in which there is conflict and contradiction are the very mark of postcolonial 'being'".

Postcolonialism generally refers to studies engaging with the legacy of European colonial systems. There are different forms of postcolonialism and this study is theoretically framed within discursive postcolonialism. According to Hitchcock (1997) the uniqueness of discursive postcolonialism is in that it "assesses the condition of postcoloniality as a discursive construction" (p.233). Evidently, the role of theory in this study is to inform methodological decisions, since it foregrounds discourse as a crucial aspect of 
understanding postcolonial constructions. Discourse is informed by the linguistic turn, whose basic premise is that "meaning does not exist outside language" (Dimitriadis and Kamberelis, 2006). Therefore since the linguistic turn, text has ceased to be viewed as written language only, but according to Halliday (as cited in Alba-Juez, 2009), "text is everything that is meaningful in a particular situation" (p.6). Discourses create and make concepts real through the process of "actualisation" and these ideas are modified into dominant discourses through a process of articulation (Howarth, Norval and Stavrakakis, 2000). Therefore educational media such as history textbooks become tools for the dissemination of the discourses from above and the users become "disciplined subjects" of such discourses (Dimitriadis and Kamberelis, 2006, p.112).

\section{Methodological considerations}

Employing purposive sampling, I consciously selected four History textbooks from different publishers in the country as summarised in Figure 1 below. I chose four contemporary history textbooks for analysis. The sampling was purposive based on the textbooks' fitness of purpose for the study (Babbie, Mouton, Vorster, Payze, Prozesky and Boshoff, 2008). 


\begin{tabular}{|l|l|c|l|}
\hline \multicolumn{1}{|c|}{ Title } & \multicolumn{1}{|c|}{ Author(s) } & $\begin{array}{c}\text { Date of } \\
\text { publication }\end{array}$ & \multicolumn{1}{|c|}{ Publisher } \\
\hline $\begin{array}{l}\text { Textbook 1 (Shuters } \\
\text { history Grade 12) }\end{array}$ & Bartels, J. et al. & 2006 & Shuter \& Shooter \\
\hline $\begin{array}{l}\text { Textbook 2 (Making } \\
\text { history Grade 12) }\end{array}$ & Claire, H. et al. & 2007 & Heinemann \\
\hline $\begin{array}{l}\text { Textbook 3 (Focus on } \\
\text { history: Looking into } \\
\text { the past Grade 12) }\end{array}$ & Friedman, M. et al. & 2007 & Maskew Miller Longman \\
\hline $\begin{array}{l}\text { Textbook 4 (Oxford in } \\
\text { search of history } \\
\text { Grade 12) }\end{array}$ & Bottaro, J. et al. & 2006 & Oxford University Press \\
\hline
\end{tabular}

Figure 1: The research sample ${ }^{3}$

International trends in textbook research show that researchers more often than not do not analyse entire textbooks. Instead they select particular sections or themes in the textbooks which they view to be of relevance to their research focus (Cobble and Kessler-Harris, 1993; Holt, 1995; Mazel and Stewart, 1987; 2003; Ogawa, 2004; Aldridge, 2006; Romanowski, 2009). Based on such evidence from literature, I elected to generate data from the chapters which focus on themes on post-colonial African history. The relevant theme in the textbooks featured as 'Uhuru', a Swahili word for freedom. This was the most appropriate theme since it is the only theme in the curriculum that deals with post-colonial Africa and my study focused on the construction of the post-colonial African being. I made use of two of Nicholls' (2003) and Pingel's (2010) criteria for analysis: descriptive author's text (narrative); and visuals (such as illustrations, photographs/pictures, maps, tables, statistics, graphs and other sources).

The Critical Discourse Analysis (CDA) methodology is not specifically fashioned for history textbook research. However, its relevance is based on its emphasis on language and context. The context within which the textbooks

3 I analysed NCS textbooks as the CAPS books were not yet produced when this study started. The CAPS Grade 12 textbooks were only distributed for use in 2014 and by that time, I had already finished my analysis. 
are produced influences the discourses of Africanness that emerge from the textbooks. The link between power and educational media such as textbooks is explained by the concepts of the macro-level and micro-level of discourse. Van Dijk (2003) explains how discourses operate at the macro-level of the power holders and at the micro-level of the average citizen. Using this thinking, it can be argued that dominant controllers of the context (usually the politicians) purvey certain discourses which play a part in the construction of an African consciousness within the ordinary citizen. At a micro-level, schools and educational media (particularly textbooks) also purvey their discourses which either augment or sometimes contest the construction done from the macro-level. Studying from such a perspective helps to identify where these levels meet and Van Dijk (2003, p.354) calls this meeting space the "meso-level" of discourse.

Since there are several variations of CDA I focused on Norman Fairclough's (1995) CDA which entails three dimensions of discourse analysis:

description, interpretation and explanation. Although I and present the findings according to these three dimensions of analysis as I did not analyse them as independent, as one would not make sufficient meaning without the others (Janks, 1997). I relied heavily on the article by Janks (1997) which is an example of how Fairclough's CDA was applied in practice.

For the descriptive analysis, I selected five aspects of functional grammar; lexicalisation; referential cohesion devices; the use of nominalisation; the use of active and passive voice; and patterns of transitivity (Janks, 1997, p.335). These aspects are linked to Halliday's (1985) systemic functional linguistics. I also applied visual semiotics though which visuals are signs which comprise signifiers that represent a particular meaning (the signified). The interpretation and explanation relied on literature, theory and the context. These methodological moves are fully explained in another article (Maposa, 2015).

\section{Description of findings}

Through the analysis, data was coded and grouped into themes. Eventually the analysis produced five major themes. These themes are presented here as notions that actualise the African being. The five notions represent the manner in which the African being is constructed in the textbooks and they 
are: the spatial, the physical, the philosophical, the cultural and the experiential. Within these themes there were both constructions and contestations of the description of Africanness and there were also some findings that overlapped across themes.

The spatial notion of the African being refers to the African as determined by space. This notion revealed that while the continental space was a factor, it was not always the determinant of Africanness. There are references to Africans both in Africa and abroad (Textbook 3, pp.49; 90). However, the description also showed that there are some people in Africa who might not qualify as Africans. For example, Textbook 1 (p.101) refers to "whites living in South Africa", rather than saying "white South Africans." The former implies a sense of not belonging to South African while the latter implies belonging through citizenship. The visual text constructed the African being to be either born or found in the African continent, with the emphasis of those from sub-Saharan Africa. There was also notable exclusion of South Africans and people from islands of Africa. In fact, both forms of text denote the exclusion of some people on the African continent from Africanness, especially so when race is considered. Therefore, the spatial notion of the African being is constructed in ambiguity.

Regarding the physical notion, race features as a major criterion of Africanness. The African being is constructed in both the verbal and visual text as Black. In fact, all the textbooks use African and Black interchangeably. In addition, the textbook visuals feature almost entirely Black characters such as Kwame Nkrumah, Patrice Lumumba, Mobutu Sese Seko, Haile Selassie, Julius Nyerere and Idi Amin. However, the use of the term "Black African" in Textbook 3 (p. 95) seems to qualify that there are other Africans who are not necessarily Black. None of the textbooks explicitly refers to the Africanness of racial groups such as Arabs. For instance, Abdul Gamal Nasser is mentioned in reference to him being a Pan-Arabic leader who "believed in unification across borders" leaving his Africanness rather ambiguous (Textbook 1, p.64), while Whites are excluded from Africanness. In addition, although there was some female representation, the African is physically represented as largely male. In Textbook 3 , there are only two mentions of women, the first being Miriam Makeba, a musician (p.96), and the second being the citation of women's organisations opposing post-colonial African dictatorships (p.101). 
In the construction of the cultural notion of the African being there was representation of aspects such as language, arts, tradition, religion and, to a lesser extent, ethnicity in the verbal text. Textbook 2 and 3 raise the linguistic diversity of Africans while English, French and Portuguese retain the tag of "colonial languages". However, the same textbook contradicts itself by regarding Soyinka's novel, The Interpreters, (written in English) as "the first truly African novel" (Textbook 3, p.95). The visual text focused more on dress and gender roles. Even though there were also cases of generalisation of the African being, African culture was constructed as flux, with strong evidence of the acceptance of hybridisation of cultures. Figure 2 shows examples of normalisation of hybridisation in terms of attire and accessories. Therefore, the African being is largely represented as a cultural hybrid, with a marked representation of the influence of Western culture. Where a distinction is made, African culture is represented as traditional, while Western culture is represented as modern.

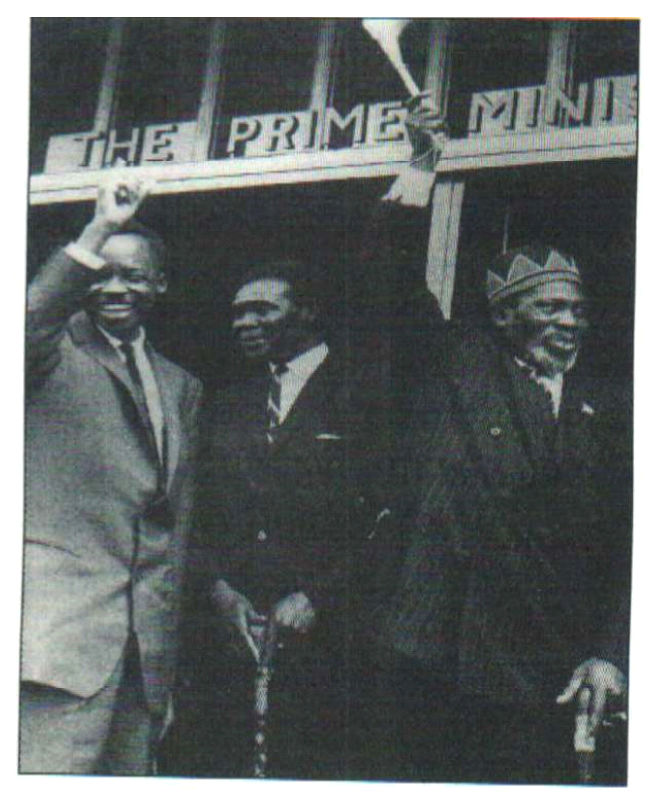

President Julius Nyerere of Tanzania, President Apollo Milton Obote of Uganda and President Jomo Kenyatta of Kenya

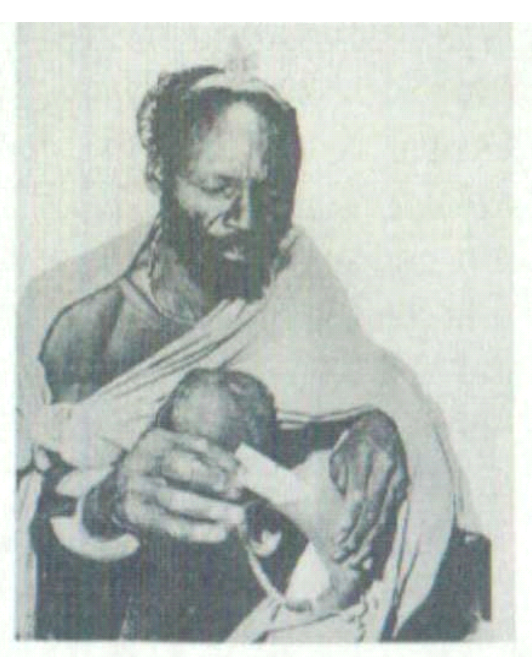

The mixture of different worlds is seen in this photograph from 1973 of a voter storing his voter's card in his snuff horn.

Figure 2: Examples of normalisation of hybridisation (Textbook 2, p.49; Textbook 4, p.88) 
The experiences that make the African being are represented as largely negative. All the four textbooks emphasise post-colonial African problems such as lack of development, wars, poverty, and oppression by both internal and external forces. They identify the 1960s as the only period of notable positive experience and there is little reference to the contemporary experiences of the 21 st century. South Africans are excluded from most of the negative constructions of Africa, The visual text describes some positive experiences such as access to education and cases of gender equality. However, most of the experiences that could be considered as positive are also represented as fundamentally symbolic. There are also contending representations of the agency of the African being in the textbooks as the Africans are, in some cases, represented as victims, while, in other cases they are as participants in determining their own fate.

The final theme was on the philosophical notion of the African being which was constructed through the representation of concepts and values that were associated with the African being. The concepts in the textbooks include Uhuru, Ubuntu, harambe, Ujamaa and chimurenga. Evidently, most of such concepts are in Swahili and not from different parts of Africa. There are also African variations of otherwise universal concepts. These include "African Renaissance" (p.79) and "African nationalist" (Textbook 1); "African unity", "African identity" and "African elite" (Textbook 2); "African traditions", "African literature" and "African novel" (Textbook 3) and "African music, art and literature" (Textbook 4). Here, the representation was that of an African being with hybrid philosophies with a mixture of African communalism and Western thoughts. The philosophy of the African being is also represented as ideally progressive and positive, but practically negative, particularly because it has led to the negative experiences previously identified. Nevertheless, the African being is constructed as having a positive outlook for the future, which is also idealistic. Visually, the African being is constructed as someone who has their own epistemology as revealed by ideals and values of equality, unity and cooperation in some of the pictures in the textbooks. However, practically the African being is constructed as having a philosophy which enables oppression and inequality.

\section{Interpretation of findings}

The spatial notion reveals that, on one hand, an African is someone who is from the continent of Africa. Such a construction tallies with the typology of Africanness as presented by Dei (1994) and Mazrui (2005) who refer to 
Africans by birth and Africans of the soil respectively. However, the emphasis on sub-Saharan Africa, thus excluding North Africa and the islands, speaks to cases of exceptionalism to Africanness, whereby their inhabitants are excluded from the African discourse (Grinker and Steiner, 2005; Mamdani, 1999; Collins and Burns, 2007). The complication is furthered by the finding that, even in sub-Saharan Africa, some people are excluded from the African designation. This is especially so in South Africa whereby other criteria such as race come into play. It is also on the basis of race that the textbooks, on the other hand, do not delimit Africanness to inhabitants of the African continent, but also to the Diaspora. As a result the meaning of the spatial notion of the African being is unstable, as was discussed in the literature review, leaving it to other notions to stabilise it.

The physical notion showed the African being represented as largely Black and male. There is evidence of African nationalist discourse which equals Africanness to Blackness (Mazrui, 2005; Mboukou, 1983; William, 2003). It tallies with discourses in South Africa whereby Black people are officially referred to as Africans. This meaning of Africanness, leave population groups such as the Arabs and Whites in a position of ambiguity, if not exclusion to discourses of Africanness, while Black people out of Africa become included. Nevertheless, linguistic choice of "Black African" (though very limited) can also be interpreted to imply that there are other Africans who are not Black as contended by Armah (1999). The representation of the African as male speaks to the oft referred to perpetuation of patriarchy and as part of a broader problem of women not featuring in history textbooks in general (Fardon and Schoeman, 2010).

The cultural notion of the African being in the verbal text was interpreted to have more complicated meanings. African culture is represented as homogenous on one hand, thus relating to arguments by Dei (1994) and Grinker and Steiner (2010) that there is some form of cultural uniformity amongst Africans. On the other hand, it is constructed as multifarious (Appiah, 1992; William, 2003). But what further complicated the meaning is that African culture is also represented as hybrid, but is still acceptably African. In fact, the hybrid representation is the most dominant. This construction speaks Baker Jr. et al. (1995) reminder that returning to native wholeness in a post-colonial society is practically impossible, such that all postcolonial phenomena are invariably hybridised. It can be concluded that cultural hybridity is the hallmark of the post-colonial African being in the textbooks. 
The African being is also represented as having undergone largely diverse, thus hybrid, experiences. But as was the case with the experiential notion of Africa, there is evidence of a level of a dual assumption when it comes to the African being. As shown in the description of findings, many of the negative experiences that are attached to the African being are generalised to sub-Saharan Africans, in this way excluding the North Africans, South Africans and the islanders. This exceptionalism can be connected to Mbeki's lamentation that South Africans seemed not to be quite African (Adebajo, 2004). Another key finding is that the experiential notion is differentiated between that of the political elite and the African populace. Therefore the experiential meaning of the African being in the verbal text is also unstable and depends on to whom it is being referred. This contradicts William's (2003) assertion that Africans should share a common memory of experiences. Africans are represented as having together suffered mainly negative experiences.

Finally the meaning of the philosophical notion of the African being is more generalised than contested within the analysed textbooks. The construction of a largely uniform African philosophy was based on the adoption of concepts such as Uhuru as African concepts which can be used as common denominators. African philosophy is also represented as part of the global knowledge system to which it both contributes and from which it borrows (Guèye, 1999; Gupta, 2012; Ocholla, 2007; Sefa Dei, 2002). The contribution of South Africa in this regard is not portrayed as considerable as most values and concepts that are referred to are from other African societies.

The interpretation showed that the meanings of Africa and the African being were riddled with multiple meanings with hybridity and ambiguity which Bakhtin (1981) would refer to as heteroglossis. The strong featuring of ambiguity gives credence to Guèye's $(1999, \mathrm{p} .247)$ view that some of the criteria that have often been used to determine Africanness are "purely phenomenal, superficial dimensions". I noted in the literature review that Armah (1999) states how aspects such as geographical location, race, language, culture, attitude and experiences have been used to qualify one as an African. The textbooks that I analysed confirmed some of these notions, but other notions also emerged from the analysis.

These constructions show how the two concepts cannot be taken for granted, such that while they are sources of emotional contestations, other quarters have even dismissed them as imaginary and non-existent (Van Dijk, 2006). 
However, other scholars such as Ottaway (1999) contend that while Africanness is invented, it can actually become real. The constructions in the analysed textbooks manifest this process of the two concepts being actualised through discourses. This interpretation is supported by Chinua Achebe's statement that: "There isn't a final identity that is African. But, at the same time, there is an identity coming into existence" (Appiah, 1992, p.73).

\section{Explanation of findings}

The description and interpretation of findings showed the ambiguities and the imprecisions that characterised most of the constructions of the African being in the analysed textbooks. In Mbembe's view, (as cited in Hitchcock, 1997, p.236), the multiple dimensions of the African being reflect "“chaotic plurality,' one in which conflict and contradiction are the very mark of postcolonial 'being'." This means that it is impossible to have stable meanings in a postcolonial condition because not all the effects of colonialism can ever be undone (Baker Jr. et al., 1995, p.1047). It should also be noted that a post-conflict society such as South Africa is usually characterised by contending views, especially as it is founded on trying to come to terms with its past through embracing multiculturalism (Rüsen, 1991).

The findings further showed how the ambiguities construct an African being consciousness that is idealistic rather than fully actualised. Discursive postcolonialism further elucidates that since discourses are socially constructed, their meanings are not only contextual but are always in a state of erasure and "always elusive, always deferred, always multiple, always somewhat paradoxical" (Dimitriadis and Kamberelis, 2006, p.103). Indeed, the African consciousness that is constructed in the textbooks is elusive, deferred, multiple, and somewhat paradoxical. The textbooks therefore confirm that the African being is what Howarth and Stavrakakis (2000, p.8) refer to as an "empty signifier" - an object that is never fully meaningful such that people rely on the meanings that they get from sources like textbooks.

Exceptionalism was also a key finding in the construction of the African being. Although South African exceptionalism was not the only form of exceptionalism, it is significant for my findings because South Africa is the country in which and for which the textbooks analysed are produced. As illustrated in the background to this study, the 'othering' of Africans who are not from South Africa, particularly those from Tropical Africa is evident in 
the everyday contextual discourses in South Africa. It is also worth noting that even Western and South African discourses tend to generalise Tropical Africa, thus promoting South African exceptionalism (Mamdani, 1999). One of the reasons for such exceptionalism is the time frame of the post-colonial period (McClintock, 1993). Most of the history of post-colonial Africa that is covered in the analysed textbook sections occurred while South Africa was still under Apartheid. However, there are other historical references in other parts of Africa that occurred when South Africa was post-Apartheid.

The South African exceptionalism in most representations in the textbooks implies that the textbook users (learners and teachers in the South African education system) are meant to have a unique collective national consciousness rather than a collective African consciousness (Rüsen, 1993; Soysal, 2006). This is what Miller, Gurin, Gurin and Malanchuk (1981, p.495) refer to as a group consciousness which entails "identification with a group ... regarding the group's relative position in society along with a commitment to collective action aimed at realizing the group's interests." This means that the South African learners and teachers who use the selected textbooks may develop a confusion of different types of consciousness which is similar to the double consciousness about which Du Bois and Fanon wrote (Moore, 2005).

It is not always prudent to be formulaic and determinist about social sciences. Nevertheless, I argue that the nature of the African being that is constructed in the textbooks most likely leads to the polar affect, which, according to Miller et al. (1981), is a preference of the group one identifies with over others. The evidence is that the only time 'we' was used was in any of the analysed textbooks, it was in reference to South Africans. According to al-Badarin and Maagerø (2008) the use of the first person plural (we/us) is common in countries where the educational discourse is dominated by the promotion of a nationalistic group consciousness. This has already been proven with the cases of South African exceptionalism that is found in the analysed textbooks. On the ground in the South African context, nation-building discourses are evident as demonstrated by the common use of concepts such as 'simunye' (we are one) and 'rainbow nation'. Literature abounds on how nationalism, for all its positives, can also be malignant through othering (Hammett, 2011). In the case of this study, people from the rest of Africa, particularly Tropical Africa, are constructed as the other - just as discourses of othering were noted in the introduction to this paper. If South Africans see themselves as different from the rest of the African continent, then they can possibly develop the 
polar affect which has the potential to contribute to misunderstandings such as xenophobia. This possibility of such a development was explained by Aldridge (2006, p.663) who argues that silences and occlusion mean that learners are denied "access to relevant, dynamic, and often controversial history or critical lenses that would provide them insight into the dilemmas, challenges, and realities of living in a democratic society. .." It should be noted, though, that this development is a merely a possibility since, as noted by Paxton (1999), learners interpret text in unique ways.

Nonetheless, because of the contradictions found in the textbooks, the polar affect should not be exaggerated. There are also cases of polar power - which implies contentment or discontent over the condition in which one's group finds itself. Therefore, despite how negative or how positive Africans are constructed, South Africans are sometimes also constructed in the analysed textbooks as part and parcel of the African situation. It should be noted that the use of the first person 'we' in reference to South Africans was only seen once and therefore was not a dominant construction. However, the cases of South African exceptionalism were dominant such that the national uniqueness was evident in the analysed chapters. This is unlike the case in Germany where Soysal (2006) states that the national aspect is almost absent in the History textbooks which foreground the European dimension.

\section{Conclusion}

Education for sustainability should empower learners to develop into members of society that can contribute to development with minimum exploitation. With reference to this study, learners of history should, through the textbooks, develop a consciousness that enables unity, renewal and development in a postcolonial condition. This study has shown that while the macro-level of power produces the dominant discourses, the micro-level of the citizen also contributes to the discourses that permeate the history textbooks. Indeed, the production of textbooks is influenced by multifarious factors that when the discourses from the top and from below meet at the meso-level of textbook production, there is not just articulation but also resistance, thus producing heteroglossic representation of the African being. 


\section{References}

Adebajo, A. 2004. Africa, African Americans, and the avuncular Sam. Africa Today, 5(3), Retrieved 23 March 2011, from

http://www.jstor.org/stable/4187594

Appiah, K.A. 1992. In my father's house: Africa in the philosophy of culture. New York: Oxford University Press.

al-Badarin, M. and Maagerø, E. 2008. Addressing student readers and representation of gender - a comparative analysis of Palestinian and Norwegian textbooks in Arabic and Norwegian. Paper presented at the Ninth International Conference on Textbooks and Educational Media: Peace, Democratization and Reconciliation in Textbooks and Educational Media September 2007, Tonsberg Norway.

Alba-Juez, L. 2009. Perspectives on discourse analysis: Theory and Practice. Newcastle: Cambridge Scholars Publishing.

Aldridge, D.P. 2006. The limits of master narratives in history textbooks: an analysis of representations of Martin Luther King, Jr. Teachers College Record, 108(4): pp.662-686.

Apple, M.W. and Christian-Smith, L.K. 1991. Introduction: the politics of the textbook. In Apple, M.W. and Christian-Smith, L.K. (Eds), The politics of the textbook. New York: Routledge, pp.1-21.

Armah, A.K. 1999. Introduction. In Makgoba, M.W. African renaissance. Cape Town: Tafelberg.

Babbie, E., Mouton, J., Vorster, J., Payze, C., Prozesky, H. and Boshoff, N. 2006. The practice of social research. Oxford: Oxford University Press.

Baker Jr. H.A., Dovey, T., Jolly, R. and Deinert, H. 1995. Colonialism and the postcolonial condition. PMLA, 110(5), 1047-1052. Retrieved 23 February 2010, from http://www.jstor.org/stable/463029

Bakhtin, M.M. 1981. The dialogical imagination. Austin: University of Texas Press. 
Bhabha, H.K. 1994. The location of culture. London: Routledge.

City Press. 2012. Zuma scolds 'clever' blacks. City Press online, 3 November 2012. Retrieved 05 November, from http://www.citypress.co.za/news/zuma-scolds-clever-blacks-20121103/

Chisholm, L. 2013. The textbook saga and corruption in education. South African Review of Education, 19(1): pp.7-22.

Cobble, D.S. and Kessler-Harris, A. 1993. The new Labor history in American history textbooks. Journal of American History, 79(4): pp.1534-45.

Collins R.O. and Burns, J.M. 2007. A history of sub-Saharan Africa. Cambridge: Cambridge University Press.

Crawford, K. 2000. Researching the ideological and political role of the history textbook - issues and methods. International Journal of History Learning, Teaching and Research, 1(1).

Dei, G.J.S. 1994. Afrocentricity: a cornerstone of pedagogy. Anthropology and Education Quarterly, 25(1): pp.3-28. Retrieved 22 March 2011 from http://www.jstor.org/stable/3195745.

Department of Education. 2000. Report of the History/Archaeology Panel to the Minister of Education. Retrieved 23 June 2012 from http://education.pwv.gov.za/Policies+Reports/2000.

Diakanyo, S. 2010. We are not all Africans, black people are! Retrieved 26 March 2011, from http://www.thoughtleader.co.za/sentletsediakanyo/2010/12/28/we-are-not-allafricans-black-people-are/

Dimitriadis, G. and Kamberelis, G. 2006. Theory for education. New York: Taylor and Francis.

Diop, C.A. 2000. Towards the African Renaissance: Essays in African Culture and Development, 1946-1960. New Jersey: Red Sea Press.

Dlanga, K. 2011. White people are African too! news24.com, 4 January, 2011. 
Donlan, A. 1980. Locating main ideas in history textbooks. Journal of Reading, 24(2): pp.135-140. Retrieved 24 March 2011 from http://www.jstor.org/stable/40009294.

Duponchel, M. 2013. Who's the alien?: Xenophobia in post-apartheid South Africa. UNU-WIDER Research Paper, 3: pp.1-37.

Fage, J.D. and Tordoff, W. 2002. A history of Africa (4th Ed.). London: Routledge.

Fairfax, C. N. (2011). Locating African personhood theory and praxis: Filling the gap in social welfare programs. The Journal of Pan African Studies, (4): 5, pp.122-138.

Fanon, F. 1961. The wretched of the earth. New York: Grove Press.

Fardon, J. and Schoeman, S. 2010. A feminist post-structuralist analysis of an exemplar South African school history text. South African Journal of Education, 30: pp.307-323.

Firer, R. 1998. Human rights in history and civics textbooks: the case of Israel. Curriculum Inquiry, 28(2): pp.195-208. Retrieved 24 March 2011 from http://www.jstor.org/stable/1180134.

Foster, S. and Crawford, K. 2006. What shall we tell the children: international perspectives on school history textbooks. Greenwich: Information Age Publishers.

Grinker, R.R. and Steiner, C.B. 2005. Perspectives on Africa: a reader in culture, history and representation. New York: John Wiley and Sons.

Guèye, S.M. 1999. African Renaissance as an historical challenge. In Makgoba, M.W. African renaissance. Cape Town: Tafelberg.

Gupta, A.D. 2012. Way of communication in indigenous knowledge related studies. International Journal of Management and Social Sciences, 1(2): pp.279-286.

Halliday, M.A.K. 1985. An introduction to functional grammar. London: Edward Arnold. 
Hammett, D. 2011. British media representations of South Africa and the 2010 FIFA World Cup. South African Geographical Journal, 93(1): pp.63-74.

Harris, B. 2002. Xenophobia: A new pathology for a new South Africa? In Hook, D. and Eagle, G. (Eds), Psychopathology and social prejudice. Cape Town: University of Cape Town Press, pp.169-184.

Hitchcock, P. 1997. Postcolonial Africa? Problems of theory. Women's Studies Quarterly, 25(3/4): pp.233-244. Retrieved 23 February 2010 from http://www.jstor.org/stable/40003387

Hollinger, D.A. 2005. The one drop rule \& the one hate rule. Daedalus Winter, pp.18-28.

Holt, T.C. 1995. Reconstruction in United States history textbooks. The Journal of American History, 81(4): pp.1641-1651. Retrieved 24 March 2011 from http://www.jstor.org/stable/2081653.

Howarth, D., Norval, A.J., Stavrakakis, Y. 2000. Introducing discourse theory and political analysis. In Howarth, D., Norval, A.J. and Stavrakakis, Y. (Eds), Discourse theory and political analysis: identities, hegemonies and social change. Manchester: Manchester University Press, pp.1-23.

Janks, H. 1997. Critical discourse analysis as a research tool. Discourse: studies in the Cultural Politics of Education, 18(3): pp.239-242.

LaSpina, J.A. 1998. The visual turn and the transformation of the textbook. Mahwah: Lawrence Erlbaum Associates.

Mail \& Guardian. 2013. Motshekga: Textbooks delivered ahead of deadline. Mail \& Guardian 08 January 2013. Retrieved 08 January 2013 from http://mg.co.za/article/2013-01-08-angie-motshekga-textbooks-delivered-ahea d-of-deadline.

Madonsela, T. 2013. Learning without books: report on an investigation into alleged shortages and incorrect supply of school workbooks by the National Department of Basic Education to Eastern Cape schools. Report 19 of 2013/14. 
Mamdani, M. 1999. There can be no African renaissance without an African-focused intelligentsia. In Makgoba, M.W. African renaissance. Cape Town: Tafelberg, pp.125-136.

Maposa, M.T. 2015. Reflections on applying critical discourse analysis methodologies in analysing South African history textbooks. Yesterday \& Today, 14: pp.58-75

Mazrui, A.A. 2005. Pan-Africanism and the intellectual: rise, decline and revival. In Mkandawire, T. (Ed.), African intellectuals: rethinking politics, language, gender and development. Dakar: CODESRIA, pp.56-77.

Manzo, K.K. 2004. Countries torn over baring warts in history texts. Education Week, 24(11): p.8.

Mazel A.D. and Stewart, P.M. 1987. Meddling with the mind: the treatment of San hunter-gatherers and the origins of South Africa's black population in recent South African school history textbooks. The South African Archaeological Bulletin, 42(146): pp.166-170. Retrieved 24 March 2011 from http://www.jstor.org/stable/3888743.

Mbeki, T. 1996. I am an African. Thabo Mbeki's speech at the adoption of the The Republic of South Africa Constitution Bill, 8 May 1996, Cape Town.

Mbeki, T. 1999. Prologue. In Makgoba, M.W. (Ed.) African renaissance. Cape Town: Tafelberg, pp. xiii-xxi.

Mboukou, A. 1983. The Pan African Movement, 1900-1945: a study in leadership conflicts among the disciples of Pan Africanism. Journal of Black Studies, 13(3): pp.275-288. Retrieved on from 17 October 2010 from http://www.jstor.org/stable/2784289

McClintock, A. 1993. The angel of progress: pitfalls of the term "Post-colonialism". In Patrick Williams, R.J and Chrisman, L. (Eds), Colonial discourse and post-colonial theory: a reader. Hemel Hempstead: Harvester Wheatsheaf.

McKnight, J. 2008. Through the fear: a study of xenophobia in South Africa's refugee system. Journal of Identity and Migration Studies, 2(2): pp.18-42. 
Miller, A.H., Gurin, P., Gurin, G. and Malanchuk, O. 1981. Group consciousness and political participation. American Journal of Political Science, 25(3): pp.494-511. Retrieved 18 April 2011 from http://www.jstor.org/stable/2110816.

Mirkovic, M. and Crawford, K. 2003. Teaching history in Serbia and the UK: a comparison. International Journal of Historical Teaching, Learning and Research, 3(2).

Moore, O.T. 2005. A Fanonian perspective on double consciousness. Journal of Black Studies, 35(6): pp.751-762. Retrieved 18 April 2011 from http://www.jstor.org/stable/40034879

Naseem, M.A. 2008. Texts of war/texts of peace: dismantling violence and constructing peace in textbooks and educational media. Paper presented at the Ninth International Conference on Textbooks and Educational Media: Peace, Democratization and Reconciliation in Textbooks and Educational Media, September 2007, Tonsberg Norway.

Nicholls, J. (2003). Methods in school textbook research. International Journal of Historical Learning, Teaching and Research. 3(2).

Nicholls, J. 2006. School history textbooks across cultures from the perspective of comparative education. In Nicholls, J. (Ed.), School history textbooks across cultures: international debates and perspectives. Oxford: Symposium Books.

Ocholla, D. 2007. Marginalized knowledge: an agenda for indigenous knowledge development and integration with other forms of knowledge. International Review of Information Ethics, 7(9): pp.1-10.

Ogawa, M. 2004. The treatment of Japanese-American internment during World War II in United States history textbooks. International Journal of Social Education, 19(1): pp.35-47.

Ottaway, M. 1999. Africa. Foreign Policy, 114: pp.13-25. Retrieved 22 March 2011, from http://www.jstor.org/stable/1149587 
Paxton, R.J. 1999. A deafening silence: history textbooks and the students who read them. Review of Educational Research, 69(3): pp.315-339. Retrieved 24 March 2011 from http://www.jstor.org/stable/1170542.

Pingel, F. 2010. UNESCO Guidebook on textbook research and textbook revision. Paris: United Nations Educational, Scientific and Cultural Organization/ Braunschweig: Georg Eckert Institute for International Textbook Research.

Romanowski, M.H. 2009. Excluding ethical issues from U.S. history textbooks: 911 and the war on terror. American Secondary Education, 37(2): pp.26-48.

Rodden, J. 2009. Ideology as core curriculum? Textbooks and German re-education in May 1945. The Midwest Quarterly, 50(3): pp.267-218. Rüsen, J. 1991. Historical education in a multicultural society. Yesterday and Today, 21: pp.1-7.

Said, E. 1978. Orientalism. New York: Vintage Books.

Sefa Dei G.J.S. 2002. Rethinking the role of indigenous knowledges in the academy. International Journal of Inclusive Education, 4(2): pp.111-132.

Sleeter, C.E. and Grant, C.A. 1991. Race, class, gender, and disability in current textbook. In Apple, M.W. and Christian-Smith, L.K. (Eds), The politics of the textbook. New York: Routledge, pp.78-110.

South African Police Service. 2009. South African Police Service 2008/09 annual report. Pretoria.

Soysal, Y. 2006. The construction of European identity 1945-present. In Foster, S.J. and Crawford, K.A. (Eds), What shall we tell the children? International perspectives on school history textbooks. Greenwich, CT: Information Age Publishing, pp.113-130.

Spivak, G. 1993. Outside in the teaching machine. London: Routledge.

Statistics South Africa. 2012. South African Statistics, 2012. Pretoria: Statistics South Africa. 
Statistics South Africa. 2013. Documented immigrants in South Africa, 2012. Pretoria: Statistics South Africa.

St-Pierre, P. 1997. Multiple meanings and contexts: the diversity of the post-colonial. TTR: traduction, terminologie, redaction, 10(1): pp.9-17. Retrieved 23 March 2010 from http://id.erudit.org/iderudit/037278ar

Tadjo, V. 2008. Constructing the "other" learning from the Ivorian example. Go home or die here: violence, xenophobia and the reinvention of differences in South Africa. Johannesburg: Wits University Press.

Väisänen, J. 2008. Visual texts in Finnish history textbooks. Paper presented at the Textbooks and Educational Media in the Learning Environment workshop.

Van Dijk, T.A. 2003. Critical discourse analysis. In Schiffrin, D., Tannen, D. and Hamilton, H.E. (Eds), The Handbook of discourse analysis.

Wiley-Blackwell. Retrieved 06 October 2010, from http://au.wiley.com/WileyCDA/WileyTitle/productCd-0631205969.html

Van Dijk, L. 2006. A history of Africa. Cape Town: Tafelberg.

William, I.W. 2003. Social history, African identity and the memory theory. Anthropologist, 5(4): pp.237-245.

Marshall Maposa

Faculty of Education

University of KwaZulu-Natal

maposam2@uzn.ac.za 